\title{
Social Media Management
}

Roberto E Montalvo, Ph.D., University of the Incarnate Word, USA

\begin{abstract}
The article focuses on the influence that social media is having on the corporate landscape. It offers a view of recent activity in corporate social media management hiring and contrasts it to the webmaster hiring during the mid-1990s. The hiring activity reflects the growth in time people are spending online - socially. It also describes how social media management influences brand awareness and brand reputation. It explains the core business competencies of strategy development; business analytics; creativity; and collaboration. The article cites the level of hiring as a call for academic course offerings in corporate social media management.
\end{abstract}

Keywords: blogging; brand awareness; brand reputation; microblogging; Metcalf's Law; network administrators; social branding; social media management; social media platforms; SWOT analysis; Web 2.0; Web 2.0 tools; webmasters.

\section{INTRODUCTION}

n Internet search conducted in April of 2011 for "social media manager" on Monster.com, one of the largest employment websites in the world, (Clifford, 2009), produced an excess of one thousand matches. Recently, there has been a upswing in hiring in the technology sector, (Jon, 2011), however the increase in social media manager hiring is traversing well beyond the technology sector. Companies such as Kronos, (2011), Philips, (2011), Pitney Bowes, (2011), the Princeton Review, (2011), TD-Ameritrade, (2011), and Waste Management (2011) were all seeking social media managers in April of 2011. These multi-national; human capital; personal electronics; mail-stream; standardized testing; bank holding; and environmental services companies understand the role that social media plays in their overall business strategy.

The underlying question is; where are the multi-national corporate social media managers acquiring the needed skills and expertise for these newly created positions? The demand for social media management skills and expertise is the calling of an opportunity for higher education to develop a curriculum that edifies the core competencies of social media management and produces a Web 2.0-ready manager.

\section{SOCIAL MEDIA}

Social media are fundamentally scalable communications technologies that turn Internet-based communications, (i.e., smart phones, PCs, tablet computers, portable media players, etc.) into an interactive dialogue platform. Social media platforms, such as; Delicious, Digg, Facebook, Flickr, LinkedIn, My Space, Reddit, Second Life, StumbleUpon, Twitter, Wikis, and You Tube all exist as a result of Web 2.0 (Kaplan \& Haenlein, 2010). Web 2.0 is the second evolutionary stage of the World Wide Web that collaboratively harnesses the collective intelligence of its users and emerged soon after the turn of the new millennium. The inherent value of Web 2.0 is based on its users who co-create its content that in effect increases its value with increased use. The more users a social media platform such as Facebook or You Tube has, the more useful it becomes to its community, (Karlgaard, 2005). Web 2.0 is all about the collaboration and participation between its users rather than about the developers as Web 1.0 was.

\section{SOCIAL MEDIA MANAGEMENT}

Social media management, at a business enterprise level, is the collaborative process of using Web 2.0 platforms and tools to accomplish desired organizational objectives. Social media management activity was notably visible during the commercials of Super Bowl XLV on February 6, 2011. 
Companies such as, Audi, E-Trade, and CarMax all used social media platforms that included Facebook, Twitter, and You Tube in support of their Super Bowl advertising, (Steinberg \& Schultz, 2011). Audi's "Release the Hounds," (Audi of America, 2011), commercial contained the "hashtag," (Twitter, 2011), \#ProgressIs [progress is] that prompted Twitter users to follow conversations (Tweets) about Audi's automobiles. The use of the hashtag in effect extended the duration and effect of the seconds-long commercial through subsequent microblogging (Tweeting) as did their replays on the You Tube and Facebook platforms, (Steinberg \& Schultz, 2011).

The Super Bowl XLV advertisements are examples of social media building brand awareness. In addition to developing brand awareness, it is useful in maintaining a brand's reputation. Maintaining a brand's reputation is accomplished in part by being the "...the eyes and ears of the brand as if [your] reputation depended on it...," as Chrysler, (2011) and Kronos, (2011) succinctly noted on their job postings.

Influencing and maintaining a reputation of a brand or building brand awareness requires numerous competencies. Social media management requires competencies in strategy development that is grounded in the analytics of data which in turn requires a high degree of creativity and collaboration.

Arguably, some of the better social media management job descriptions revealed in the review of literature emerged from the employment websites' own postings for social media managers. Indeed, the employment websites themselves were recruiting their own social media managers in the Spring of 2011, (Monster, 2011). Monster's (2011) summary of, “...doing well by doing good, to bring judgment, and a sense of responsibility to the wild west of social media...", was eloquently descriptive of the newness of the field of social media management. The "wild west of social media," resonates the need for developing a better understanding of the best practices and core competencies of social media management.

\section{BRAND AWARENESS}

One area that social media management readily influences is brand awareness. Brand awareness is the consumers' knowledge of a brand's existence or in general, the proportion of consumers who know of the brand. A high degree of brand awareness is a competitive advantage because of its difficulty to imitate by competitors and its ability to be leveraged across different products and markets.

Social branding or developing brand awareness through social media entails maintaining a visible company sponsored presence on social networking platforms. Organizational tweeting and blogging is necessary to regularly supply content into the platforms that increase the brand's visibility. Brand awareness in effect cultivates positive relationships with bloggers following the brand on social media.

The Twitter, ("30-Rock," 2011), and Facebook, ("30 Rock|Facebook," 2011), presence by the television series, 30-Rock, is an example of the promotion of the show's brand by a network. The show's social media presence communicates with the followers of the series on its characters or episodes thereby reinforcing its brand awareness. The benefits of the network's postings directed at the show's followers on Twitter and friends on Facebook, indirectly spill-over to the status pages of the followers of the followers and the friends of the friends multiplying exponentially its reach and influence which is known as Metcalfe's Law, (Karlgaard, 2005).

\section{BRAND REPUTATION}

According to Roberts \& Dowling, (2002), exceptional corporate reputations are important because of their potential for value creation. A brand's reputation is intangible and makes its replication by competitors difficult, thus producing another unique competitive advantage for the firm owning it. Social media management entails monitoring, identifying, and mitigating risks to the brand's reputation that may develop on social media platforms. Trusted personalities are developed on the platforms who offer an active presence as exemplified in the following blog entry from a grocery chain replying to a post regarding its manufacturer coupon policy;

My name is Brad and I work with HEB. Thanks for your question about HEB's Coupon policy! Here is a link to their official policy: http://www.heb.com/yourHEBStore/specialPromotions_CouponPolicy.jsp. If you still have 
concerns or this was not your experience at HEB, please let us know your specific store and we can address it with them. Thank you! (Southern Savers, 2010).

The brand's reputation is being maintained by providing advice and helping the customers locate the right resources in near real time through social networks. It is noteworthy that these blogs are not officially linked to the companies. The company's presence on the blog also subtlety conveys that the brand is watching what is being said about it on the social media platforms. The significance of online brand reputation management over recent years has extended to smaller firms that generally outsource their reputation management to companies such as Dunn \& Bradstreet, (Tozzi, 2011), and reputation.com, (Tozzi, 2008).

\section{STRATEGY DEVELOPMENT}

Social media management entails the development of strategic plans of action to achieve organizational goals such as increasing brand awareness and maintaining brand reputation. The organization's strategic ability to see around corners and anticipate future needs and trends as influenced by social media is essential to both its survival and growth in the Web 2.0 era. Strategy development is initiated by assessing the organization's internal strengths and weakness as well as its external opportunities and threats, known as a SWOT analysis, (Rizzo \& Kim, 2005).

The organization's own ability to regularly feed back insights gained from social media monitoring into the marketing and public relations teams would be an example of an internal strength or weakness. The business unit's ability to be forward-looking for insights that provide a glimpse of where industry is headed or trend-spotting is another example of an internal strength or weakness.

The degree of understanding of how the legal climate affects the firm's participation in social media is an example of an external opportunity or threat. Certainly the organization's ability to attract and retain a workforce fluent in Web 2.0 tools from a specific geographic area is another external opportunity or threat to be considered. Social media management strategy development in effect encompasses conducting a SWOT analysis with an emphasis on social media.

\section{ANALYTICS}

Whether the success of social media strategy is evaluated in terms of, technologies, platforms, social engagements, or customer valuations, the use of data plays a pivotal role in its analysis. Social media, by its very nature lends itself to producing an abundance of data ideally suited for analytical decision making. Social media management analytics extensively use statistical and quantitative data that facilitate fact-based decision making. According to Davenport \& Harris, (2007), data analytics are increasingly transforming marketing from an art to a science; and social media is steeped deeply in marketing's analytics.

The data on the number of times the \#ProgressIs hashmark in Audi's Super Bowl commercial was Tweeted is an easily quantifiable statistic using Web 2.0 tools. The number of times E-Trade's baby "suit fitting," (E-trade, 2011), and CarMax's "Kid in a candy store," (Carmax, 2011), commercials were watched on You Tube after the Super Bowl is another equally quantifiable statistic.

Social media data analytics entails translating data into dashboards, graphics, and metrics reports that management uses to evaluate the outcomes of specific strategies. In turn, producing useful dashboards, graphics, and metrics reports requires a working knowledge of Web 2.0 tools such as Google Alerts, Google Trends, HootSuite, Radian6, and Visible Technologies plus a good degree of creativity.

\section{CREATIVITY}

Creativity is the ability to add value through improvement and innovation, (Dobbins \& Pettman, 1997). What is considered improved may not always be in eye of the beholder, similarly what counts as an addition of value can be defined in a variety of ways. Creativity in social media management influences all of its competencies. 
Knowing how to create and distribute content that is fun, clever, and relevant is one aspect of it. Creatively responding positively to blogs negatively portraying the organization would be another role it plays. Developing unique strategies that address organizational objectives certainly requires an elevated degree of creativity. Creativity even plays a role in producing the analytical reports for management that are inviting to read. Ultimately, creativity is necessary when collaborating with others on the virtues of social media and maintaining engagement.

\section{COLLABORATION}

By its very definition, Web 2.0 and social media are based on the collaboration of its users, and it follows that social media management is a collaborative venture as well. Realizing shared organizational goals by sharing knowledge, learning, and building consensus across departments is yet another social media management competency. Interdepartmental coordination allows the leveraging of tools and techniques into the organization's social media culture and into its products and services. It ensures that a consistent message is delivered through its social media channels and avoids faux pas such as Chrysler's March $2011 \mathrm{f}-$ bomb Tweet,(Kiley, 2011).

The collaborative interactions can range from creating guidelines for social media engagement with the legal department to consulting with international marketing teams and determining how to leverage social media in their markets. Collaborative social media management requires a degree of coaching, both internal and external stakeholders on the virtues of social media and serving as the social media "evangelist". Social media management collaboration even extends beyond organizational boundaries when developing content with outside public relations agencies.

\section{CONCLUSION}

Arguably, the debut of social media badges and hashmarks in the Super Bowl XLV commercials are as noteworthy as the initial appearance of domain names alongside company logos in the mid-1990s. A decade and a half ago, the introduction of domain names in business obligated companies to fill newly created positions known as "webmasters." Webmasters needed the new skills of designing and maintaining the companies' Web presence in the Web 1.0 era.

A nostalgic look back, at how the webmaster's role differed from the existing network administrators' (preWeb 1.0) role, illustrates the contrast between social media managers and webmasters. The activity in social media manager hiring is reminiscent of the webmaster hiring of the mid-1990s, (T.H.E. Journal, 1997), and it exemplifies the new skill sets sought out by employers.

Similar to its pre-Web 1.0 and Web 1.0 predecessors, social media management is a very specialized skill. It draws from a wide range of disciplines; communications, journalism, marketing, public relations, information systems, and strategic management to name a few.

It is only a matter of time before social media managers are as ubiquitous as the network administrator and the webmaster on the corporate landscape. It is due time to include at minimum, a chapter if not an entire course in social media management to business curriculum and produce the next generation of Web 2.0-ready managers.

\section{ABOUT THE AUTHOR}

Dr. Roberto Montalvo teaches business information systems at the University of the Incarnate Word (UIW) in San Antonio, Texas. He has also taught analytical decision making and business information systems at UIW's campus in the Peoples Republic of China. Dr. Montalvo has an extensive background in the U.S. and international broadband telecommunications industry. He has held numerous management positions and assignments in the United States, Brazil, Colombia, Hungary, Mexico, the Philippines, and Spain. 


\section{REFERENCES}

1. 30 rock [Web log message]. (2011, April 12). Retrieved from http://twitter.com/\#!/nbc30rock

2. $\quad 30$ rock | facebook. (2011, April 12). Retrieved from http://www.facebook.com/nbc30rock

3. Audi of America. (2011, February 6). 2011 Audi "Big Game" commercials. Retrieved from http://commercials.audiusa.com/

4. Brown, A. (2011). Relationships, community, and identity in the new virtual society. Futurist, 45(2), 29-34.

5. Carmax. (2011, February 3). Kid in a candy store. Retrieved from http://www.carmax.com/enus/whycarmax-commercials/default.html

6. $\quad$ Chrysler. (2011, April 15). Social media community specialist. Retrieved from https://chrysler.myvurv.com//main/careerportal/Job_Profile.cfm?szOrderID=2325\&szReturnToSearch=1\& szWordsToHighlight=Social\%20Media\%20Community\%20Specialist

7. Clifford, S. (2009). In the wrong job? Monster.com Wants Your Attention. New York Times. p. 4. Retrieved from EBSCOhost.

8. Davenport, T. H., \& Harris, J. G. (2007). Competing with multichannel marketing analytics. Advertising Age, 78(14), 16-17.

9. $\quad$ Dobbins, R. \& Pettman. (1997). Development, self-development: the nine basic skills for business success. The Journal of Management. 16(8), 521-667.

10. Etrade. (2011, February 6). Tailor. Retrieved from https://us.etrade.com/e/t/jumppage/viewjumppage?PageName=etrade_super_tv_ads

11. Jon, S. (2011). Hiring is hot again for tech sector. USA Today.

12. Karlgaard, R. (2005). Ten Laws of the Modern World. Forbes, 175(10), 33. Retrieved from EBSCOhost.

13. Kaplan, Andreas M.; Michael Haenlein (2010). Users of the world, unite! The challenges and opportunities of Social Media. Business Horizons 53 (1): 59-68.

14. Kiley, D. (2011). What lurks behind Chrysler's f-bomb? Social-media turf war. Advertising Age, 82(11), 120.

15. Kronos. (2011, April 2). Manager of social media communications. Retrieved from http://www.kronos.com/careers/current-openings.aspx

16. Monster. (2011, April 5). Social media manager. Retrieved from http://jobview.monster.com/SocialMedia-Manager-Job-Maynard-MA-98070141.aspx

17. $\quad$ Philips. (2011, April 2). Social media manager. Retrieved from http://careers.peopleclick.com/careerscp/client_philips/external/en/search.do

18. Pitney-Bowes. (2011, April 5). Social media marketing research manager. Retrieved from http://www.pb.com/cgibin/pb.dll/jsp//GenericEditorial.do?catOID=-21639\&dirBiog=true1

19. Rizzo, A., \& Kim, G. (2005). A SWOT analysis of the field of virtual reality rehabilitation and therapy. Presence: Teleoperators \& Virtual Environments, 14(2), 119-146.

20. Roberts, P. \& Dowling, G. (2002). Corporate reputation and sustained superior financial performance. Strategic Management Journal. 23(12), 1077-1093. Southern Savers [Web log message]. (2010, September 29). Retrieved from http://www.southernsavers.com/2010/09/h-e-b-weekly-ad-919/

21. Steinberg, B., \& Schultz, E. J. (2011). Marketers suit up with Twitter and Facebook for 'Social Bowl'. Advertising Age, 82(5), 1-8.

22. TD Ameritrade. (2011, April 5). Social media manager. Retrieved from https://sh.webhire.com/servlet/av/jd?ai=800\&ji $=2527877 \& s n=I$

23. T.H.E. Journal [serial online]. (1997, September 2). Students can train to be webmasters. Retrieved from Academic Search Complete.

24. The Princeton Review. (2011, April 2). Social media manager. Retrieved from https://www1.apply2jobs.com/PrincetonReview/ProfExt/index.cfm?Fuseaction=mExternal.showJob\&RID $\equiv 698 \&$ CurrentPage $=1$

25. Tozzi, J. (2011). A D\&B spin-off for the Internet age. Bloomberg Businessweek, (4212), 48-49.

26. Tozzi, J. (2008). Do Reputation Management Services Work? BusinessWeek Online, 11. Retrieved from EBSCOhost. 
27. Twitter. (2011, April 10). What Are Hashtags ("\#" Symbols)? Retrieved from http://support.twitter.com/entries/49309-what-are-hashtags-symbols

28. Waste Management. (2011, April 4). Manager social media \& employment branding. Retrieved from http://wm.taleo.net/careersection/wm_cs_pro/jobdetail.ftl 